\title{
Kırsal Turizmin Gelişimine Yönelik Yerel Halkın Yaklaşımı: Avanos Göynük Köyü Üzerine Bir Araştırma
}

Local People's Approach to Development of Rural Tourism: A Research on Avanos Göynük Village

\author{
* Eda Özgül Katlav \\ ** Derman Küçükaltan
}

\section{GAS}

doi.org/10.32958/gastoria.576380

\section{Yazar Bilgileri}

\section{ORCID:}

* 0000-0002-4168-909X

**0000-0001-7670-9567

Email:

* edaozgulkatlav@gmail.com

**dermank2005@yahoo.com

\section{ÖZET}

Ön çalışma olarak gerçekleştirilen bu çalışmada, Nevşehir İlinin temel ekonomik unsurlarından olan turizm ve tarım faaliyetlerinin bir arada değerlendirilmesi ile tarım turizmi potansiyelinin ortaya konmasi amaçlanmıştır. $\mathrm{Bu}$ amaca ulaşabilmek için öncelikle turizmin bir bölgede gelişiminden en fazla etkilenecek kesim olan yerel halk ve orada yaşayan üreticilerin görüşlerinin alınması önem arz etmektedir. $\mathrm{Bu}$ kapsamda Nevşehir'in Avanos ilçesine bağlı olan Göynük Köyü'ndeki bağcılık faaliyetlerinin kırsal turizm açısından değerlendirilmesine yerel halkın kırsal turizme bakış açıları incelenmiştir. Araştırmanın amacına uygun olarak nitel (kalitatif) araştırma yöntemi ve keşifsel araştırma tasarımı kullanılmıştır ve mülakat tekniği ile veri elde edilmiştir. Araştırma kapsamında yapılan görüşmeler sonucunda yerel halkın Göynük Köyü'nde tarım turizminin gelişimine olumlu baktıkları ve bu doğrultuda çaba göstermeye hazır oldukları görülmektedir. Yerel halk turistlerin ve turistik işletmelerin köye katk1 sağlayacağını düşünmektedir. Ayrıca köy halkının kırsal turizmin uygulanabilmesi için valilik, belediyeler, üniversite, sivil toplum kuruluşları ve turizm acentelerinden yardım ve destek bekledikleri bu çalışmadaki önemli bulgulardandir.

Anahtar Kelimeler: Kırsal Turizm, Tarım Turizmi, Bağcılık, Nevşehir.

\section{ABSTRACT}

In this examination, which was done as a starter think about, it was intended to uncover the capability of horticultural the travel industry by the assessment of the travel industry and rural exercises together with the fundamental monetary components of Nevşehir Province. So as to accomplish this objective, it is imperative to take the assessments of the nearby individuals and the makers living there, which is the most influenced by the advancement of the travel industry in a locale. In this specific circumstance, neighborhood individuals' perspectives on provincial the travel industry were analyzed regarding rustic the travel industry in Göynük Village, which is associated with Avanos locale of Nevşehir. Qualitative (qualitative) research method and exploratory research design were used in accordance with the purpose of the research and data were obtained by interview technique. As a result of the interviews carried out within the scope of the research, it is seen that the local people and producers (ties) are looking at the development of agricultural tourism in Göynük Village and they are ready to make efforts in this direction. Local residents believe that tourists and tourist businesses will contribute to the village. In addition, it can be said that they expect assistance and support from the governorship, municipalities, universities, non-governmental organizations and tourism agencies in order to implement agricultural tourism in the village.

Keywords: Rural Tourism, Agrotourism, Viticulture, Nevşehir. 


\section{GíRiş̧}

Son yıllarda dünyada ve ülkemizdeki seyahat profili klasik deniz, kum ve güneş anlayışının yanı sıra alternatif turizm türlerini tercih etmeye başlamıştır. Turizmde yeni arayışlar, turistlerin beklentilerindeki değişmeler, yeni yerlerin ve yerel kültürlerin keşfine duyulan ilginin artışı, kitle turizmine tepkiler rol oynadığı gibi, özellikle de kırsal turizmin kırsal kalkınmada bir araç olarak görülmesi, giderek daha fazla önem kazanmasını beraberinde getirmiştir. Kırsal turizm ekonomik, sosyal ve psikolojik sorunların çözümünde rol alması, turizmi kıyı turizminin egemenliğinden kurtarması ve tarım üreticisine ek gelir sağlaması açısında önemli bir turizm değeridir (Çeken vd. 2007, s.7; Cengiz ve Çelem, 2005, s.168).

Kırsal turizm kırsal alanlardaki kalkınmanın sağlanabilmesinde temel kilit taşlarından biri olmaktadır. Avrupa Komisyonu (2000) tarafından yayımlanan kırsal turizm raporunda da bu görüşü destekler nitelikte bir vurgu yapılmıştır. Rapora göre kırsal kalkınmanın sağlanabilmesi için, sahil kesiminde bulunmayan turistik destinasyonlarda zengin tarımsal alanlar için öncelikler olması gerektiği belirtilmiş ve bu çerçevede çiftliklerde kaliteli konaklama sağlanması ve yerel ürünlerin geliştirilmesi gerekliliği vurgulanmıştır (European Commission, 2000, s.16). Kırsal turizmin, kırsal alanlarda yaşayan insanlara gelir ve iş olanakları sağlama, yardım sağlama gibi ekonomik açıdan olumlu etkileri vardır. Kırsal turizm sayesinde kırsal alanlardan kentsel alanlara göçler önlenebilir. Kırsal turizm, kırsal alanlarda ürün çeşitliliğine katkıda bulunarak kırsal kaynakların daha etkin kullanılmasını sağlamaktadır (Yozukmaz, Ekintepe ve Çeken, 2014, s.37). Kırsal turizm yerel boyutta kırsal istihdam sağlayarak, yerel ekonomileri canlandırarak ve göçü önleyerek sosyo-ekonomik kırsal kalkınmaya katkı vermektedir (Maruti, 2009). Ayrıca, kırsal kültürün yok olmasını önlemekte, doğal çevrelerin korunmasına destek vermekte, diğer turizm türleriyle kolaylıkla bütünleşebilmektedir. Değişik alanlarda turizmin yapılması, yıl içinde uzun süreli faaliyet yapılmasını ve yılın hemen hemen her döneminde turist çekmesine olanak sağlamakta ve gelir dağılımında bölgeler arası farkları azaltarak adalet sağlaması açısından da ayrıca öneme sahiptir.

Kırsal turizm, kırsal alanlarda yöre halkının hem ekonomik olarak gelişmesi, hem de turizm sektöründe önemli kazanımlara yol açması nedeniyle dikkate alınması gereken bir turizm çeşididir. Bu açıdan Göynük Köyü için yapılacak çalışmalar bu yörenin hem ekonomik, hem de kültürel anlamda gelişmesini sağlayacaktır. Dünyada önemli bir gelişme gösteren kırsal turizmin en önemli destekleyici unsurlarından biri yöre halkının turizme bakış açısıdır. Bu nedenle Göynük Köyü'nde yaşayan yerel halkın ve üretim yapan çiftçilerin kırsal turizme olan bakış açısının incelenmesi önemlidir. Bu çalışmanın amacı temel ekonomik kaynakları tarım ve turizm olan ve bağcılıkla ilgili önemli bir tarihi bulunan Nevşehir İline bağlı Göynük Köyü'nde tarım turizminin yapılabilirliğine yönelik bir ön çalışma yapmaktır. Buradan hareketle Nevşehir'in Avanos ilçesine bağlı Göynük Köyü'nde bir kırsal turizm türü olan tarım turizmi olanakları ve uygunluğu açısından köy halkının "kırsal turizm" veya "tarım turizmine" yönelik tutumlarını ortaya koymak amaçlanmaktadır. 


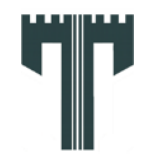

Gastroia: Journal of Gastronomy and Travel Research, Vol. 3, Issue 4 (Özel Sayl), 739-752, 2019

Kırsal Turizmin Gelişsimine Yönelik Yerel Halkın Yaklaşımı: Avanos Göynük Köyü Üzerine Bir Araştırma Eda Özgül KATLAV, Derman KÜÇÜKALTAN

\section{KAVRAMSAL ÇERÇEVE}

Kırsal turizm, insanların devamlı ikamet ettikleri yerler dışındaki kırsal yörelere ziyaretleri, buralarda tarım üreticilerinin ürettikleri mal ve hizmetleri, yörenin doğal dokusuna uygun mekânlarda talep ederek ve yörede para arttırma arzularını minimize ederek geçici konaklamalarından doğan olaylar ve ilişkilerin bütünü olarak tanımlanmaktadır (Küçükaltan ve Ultanır, 2012). Kırsal turizmin kırsal kalkınmaya etkisi daha çok yöredeki tarihi, doğal, kültürel ve tarımsal kaynakların etkin bir şekilde kullanılmasıyla orantılıdır (Çeken ve ark. 2007). Kırsal turizmde mevcut yöresel olanakların değerlendirilmesiyle sağlanan gelir, doğrudan kırsal kesim insanının kazancı olmaktadır. Özellikle bölgede üretilen tarımsal ürünler yine işlendikleri yerde satılmakta, köy evleri pansiyon olarak hizmet vermektedir. Köylere, çiftliklere günübirlik ziyaretlerle gelenler, sebze, meyve, reçel, peynir, zeytinyağı, şarap ve şarküteri ürünlerini satın aldıkları gibi, restoranlarda aynı ürünleri tatma imkanı bulmaktadır. Konaklamalı gelenler ise, otantik evlerde gecelemekte, kalış süreleri içinde bir dizi etkinliklere katılmaktadırlar. Söz konusu etkinlikler içinde tarımsal üretimle doğrudan ilgili olanların yoğunluğu fazla ise kırsal turizmin bu türüne tarımsal turizm (agroturizm) ya da çiftlik turizmi de denilebilmektedir.

Kırsal turizm ve tarım turizmi arasındaki ilişki incelendiğinde kırsal turizm genel olarak kırsal arazilerde gerçekleştirilirken, tarım turizmi tarımsal alanlarda gerçekleşen turizm faaliyetlerini kapsamaktadır ( Topcu, 2007,s.25). Tarım turizmi ile ilgili literatür incelendiğinde kavram " "kırsal kesimde tarımda çalışan insanlar tarafindan geliştirilmekte olan küçük ölçekli, aile veya kooperatif kökenli turist faaliyetler” olarak tanımlanmaktadır (Kizos ve Lozifides, 2007, s.63). Kırsal turizm kavramı kırsal alanlara yönelik genel bir çerçeveyi içine alırken bu turizm türü kapsamında sadece özel olarak tarımsal alanlara, bağlara, bahçelere yönelik gerçekleştirilen ziyaretler tarım turizmi içerisinde yer almaktadır. Dolayısıyla kırsal turizm; tarım turizmi, çiftlik turizmini de içine alan daha geniş kapsamlı alternatif bir turizm türüdür. araştırmamız kapsamındaki göynük de içinde tarım ürünlerinin ağırlıkta olduğu kırsal turizme uygun bir yapı sunmaktadır.

\section{Nevşehir'in Kursal Turizm Potansiyeli}

Nevşehir ilinde ana geçim kaynağı tarım ve turizmdir. Nevşehir'de temel ekonomik faaliyetler turizm sektörü ekseninde gelişmekte olup diğer öne çıkan sektörler bims blok üretimi (pomza sektörü), tarım makineleri imalatı, karoser ve ekipmanları imalatı, soğuk hava depoculuğu ve tarım sektörüdür (Ahika, 2017, s.5). Nevşehir'de en fazla ithalat yapılan sektörlerin başında tarım ürünleri gelmektedir. Ayrıca yine Nevşehir'de turizm ile birlikte en fazla istihdamın sağlandığı sektör tarımdır. Nevşehir'de hâlihazırda 352.218 ha alan tarıma elverişlidir. Nevşehir genelinde tarımsal üretim arazi kullanımının \%58,7'sini tahıllar oluşturur. Diğer önemli ürünler üzüm başta olmak üzere patates, çekirdeklik kabak, pancar, ay çekirdeği ve baklagillerdir. Nevşehir, 2015 yılı sonu itibarıyla kabak çekirdeği ve şaraplık üzüm üretimi bakımından ülkemizde ikinci sırada, çavdar ve kuru fasulye üretimi bakımından ise ülkemizde üçüncü sırada yer almaktadır (Ahika, 2017, s.25).

Nevşehir'de tarımsal ürün olarak en fazla üretilen ürün üzüm olmaktadır. Orta Anadolu Bölgesinde yer alan Nevşehir İlinde bağcılık tarihi çok eskiye dayanmaktadır (Yalçın, 2006). Bölgenin yer altı şehirlerinden elde edilen bilgilere göre; üzüm çiğneme ve şarap 
üretme alanlarının var olduğu bölgede üzüm yetiştiriciliğinin ve şarabın M.Ö. 3000’li yıllara (Hitit dönemi) kadar uzandığı düşünülmektedir (Türkben ve diğerleri, 2012). Kapadokya bölgesi, geçmiş yıllardan bu yana üzüm bağları ile Türkiye'de bağcılık ve üzüm yetiştiriciliğinde önemli bir konumda yer almaktadır. Nevşehir'de üretilen Emir, Parmak üzümü ve Dimrit üzümleri arasında en fazla bilinen üzüm çeşitlerdir (Uysal ve Yaşasın, 2017). Son yıllarda ilde özellikle kaliteli şarap elde edilen ve getirisi yüksek olan Cabernet Sauvignon, Chadonay, Merlot ve Gamay üzüm çeşitlerinin üretilmesine yönelik bir eğilim olduğu görülmektedir. Ancak eskiye oranla günümüzde bölge halkının temel geçim kaynağı bağcılıktan turizme doğru bir eğilim göstermiştir. Bölgenin turizm açısından zengin bir potansiyele sahip olması ve turizm talebinin artmasıyla özellikle turizmin yoğun olarak yapıldığı ilçe ve kasabalarda bölge halkı bağcılığa daha az ilgi gösterdiği göstermeye başlamıştır. Ancak bağcılık faaliyetleri tamamen sonlanmamış halen bazı köy ve kasabalarda bağcılık aktif bir şekilde yapılmaktadır. Bu alanlarda turizm faaliyetleri yapılmamakta sadece bağcılık ya da tarımsal ürünler üretilmektedir. Kırsal turizm ya da tarım turizmine yönelik bir girişim bulunmamaktadır (Ahika, 2017; Kapadokya Bağcılık Çalıştayı, 2016; Kiracı ve Şenol, 2017;Semerci, ve diğerleri, 2015).

Nevşehir İlinde turizm faaliyetleri aktif bir şekilde devam etmektedir. Fakat bölgeye gelen turistlerin genellikle geliş amaçları genellikle kültür ve inanç turizmi olmaktadır. Ancak yapılan araştırmalar, son zamanlarda bölgeye gelen turistlerin kırsal turizm faaliyetlerine yönelik turistlerin talepleri olduğunu göstermektedir (Tuna, Katlav ve Eren, 2018). Bu kapsamda bu araştırmanın amacı Nevşehir İlinde bağcılık yapılan köylerin kırsal turizm potansiyelini ortaya çıkarmaktır. Bu kapsamda Nevşehir'de bağ alanların en fazla olduğu Göynük Köyü araştırma alanı olarak seçilmiştir. Bu nedenle kırsal turizmin planlanabilmesi için önemli aktörler olan yerel halk ve üreticilerin görüşlerine başvurmak istenmiştir. Bu amaçla köyde turizm faaliyetlerinden doğrudan etkilenecek yerel halk ve üreticileri (bağcılar) konu hakkında tutumlarını öğrenmek amacıyla görüşmeler yapılmıştır.

\section{YÖNTEM}

\section{Araştırmanın Amacı ve Soruları}

Bu çalışmada, Türkiye'de bağcılık için önemli merkezlerden biri olan Nevşehir İline bağlı Göynük Köyü'nde bağcılığın mevcut durumu ortaya konularak bu köyde bağcılık ve turizmin bir arada yapılmasına imkan sağlayan kırsal turizmin köyde yapılabilirliği üzerinde durulmuştur. Buradan hareketle bu çalışmanın temel araştırma sorusu 'Nevşehir' de kırsal turizmin geliştirilmesine yönelik mevcut durum ve yapılması gereken düzenlemelerle ilgili yöre halkı ve çiftçiler (bağcılar) ne düşünmektedir?" şeklinde ifade edilebilir. Nevşehir'de bağcılık ve turizmle ilgili paydaşların görüşlerinin derinlemesine incelenebileceği ve bağcılık ve turizm faaliyetlerinin bir arada gerçekleştirilebileceği kırsal turizm potansiyelinin nasıl değerlendirilebileceğine ilişkin ayrıntılı verilere ulaşılabileceği düşünülmektedir. $\mathrm{Bu}$ nedenle çalışmada, disiplinler arası bütüncül bir bakış açısı esas alınarak, araştırma problemini yorumlayıcı bir yaklaşımla incelemeyi benimseyen nitel araştırma yöntemine başvurulmuş ve nitel veri toplama araçlarından görüşme (mülakat) tekniği kullanılmıştır.

Bağcılık ve turizm ilişkisi üzerine doküman taraması 25 Aralık 2017-10 Ocak 2018 tarihleri arasında internette taranan dokümanlar makale, çalıştay raporları, kamu kurumları 
Kırsal Turizmin Gelişsimine Yönelik Yerel Halkın Yaklaşımı: Avanos Göynük Köyü Üzerine Bir Araştırma Eda Özgül KATLAV, Derman KÜÇÜKALTAN

ve sivil toplum kuruluşları tarafından yayımlanan istatistikler ve röportajlar üzerinden yapılmıştır. İncelenen dokümanlar, coğrafi kıstasa göre ulusal ve bölgesel olmak üzere; "Türkiye'de bağcllık ve turizm üzerine dokümanlar" ve "Nevşehir'de bağcılık ve turizm üzerine dokümanlar" iki grup şeklinde ele alınmıştır. Araştırma esnasında dokümanlara bağcılık, bağcılık ve turizm, kırsal turizm, tarım turizmi, Nevşehir ve bağcılık, gibi anahtar kelimeler kullanılarak erişilmiştir. Soru formundaki olası sorular içerik analizi sonucu elde edilen doküman incelemesinin bulguları ve ilgili literatürden yararlanılarak oluşturulmuştur. Hazırlanan olası görüşme soruları araştırmacılar tarafından tekrar incelenmiş ve ardından taslak şeklinde bir görüşme formu hazırlanmıştır. Hazırlanan taslak soru formu bu konuda uzman olan akademisyenlerin görüşüne sunulmuş ve önerileri doğrultusunda gerekli düzeltmeler yapılmıştır. Görüşme formunda, Göynük Köyü’nde kırsal turizm potansiyelinin yerel halk ve çiftçiler (bağcılar) bağlamında nasıl değerlendirildiğine ilişkin sorular yer almaktadır.

\section{Araştırmanın Örneklemi}

$\mathrm{Bu}$ çalışmada olasılıklı olmayan örnekleme yöntemlerinden, amaçlı örnekleme yöntemi çerçevesinde azami çeşitlilik örneklemesine başvurulmuştur. Azami çeşitlilik örneklemesi, araştırma yapılan bölgede araştırmaya katılan bireylerin çeşitliliğine dayanmaktadır ve bir grubun özelliklerinin daha iyi temsil edilmesine imkân vermektedir (Seidman, 2006). Buna göre araştırmanın örneklemine dahil edileceklerin Göynük Köyü’nde söz sahibi olan kişilerden seçilmesine özen gösterilmiştir. Bu ölçütlere göre görüşme yapılacak olası kişiler belirlendikten sonra iletişim bilgileri kullanılarak her birine önce telefon aracıllı̆̆ıyla ulaşılmış ve kısa bir şekilde araştırmanın amacı ve içeriği ile araştırmacının kimliği açıklanmıştır ve görüşme günü ve saati belirlenmiştir. Nevşehir'de bağcılık Avanos, Ürgüp ve Gülşehir ilçelerinde yoğun bir şekilde yapılmaktadır. Bu araştırmada Göynük Köyü’nün seçilmesinin nedenleri şöyle sıralanabilir; burada turizme uygun bağ alanlarının bulunması, köyde büyük miktarda üretim yapılması, turizm alanlarına yakın mesafede olmasıdır. Araştırma Göynük Köyü’nde bağcılık ve tarım turizmine ilişkin değerlendirmeyi kapsamlı bir şekilde yapabilecek yerel halk ve Göynük Köyü'nde Göynük Yaş Sebze ve Meyve Kooperatifi Üyesi bağcılık yapan üreticilerin seçilmiş kişilerle yapılmıştır.

Araştırmaya katılmayı kabul eden katılımcılardan yüz yüze görüşme yapılabilmesi için randevu istenmiş ve randevu listesi oluşturulmuştur. Görüşmelerin tamamı, gönüllülük esasına dayalı olarak araştırmacı tarafından gerçekleştirilmiş ve 28 Şubat- 10 Mart 2019 tarihleri arasında katılımcılarla Göynük Köyü’nde görüşme yapılmıştır. Bu bağlamda köyde yaşayan yerel halk, kooperatif üyeleri ve bağcılar olmak üzere 13 paydaş örnekleme dahil edilebilmiştir. Nitel araştırmalarda yapılan görüşmelerde aynı şeyler tekrar edilmeye başlandığında ve elde edilen veriler yeterli düzeye geldiğinde katılımcı sayısını fazlalaştırmaya ihtiyaç duyulmamaktadır (Miles ve Huberman, 1994). Görüşülen her paydaşa önce araştırmanın içeriği ve amacı hakkında bilgi verilmiş, gönüllü katılımcı bilgilendirme formunu doldurmaları istenmiş ve alınan izin ile görüşmeler ses kayıt cihazı ile kayıt altına alınmış ve ayrıca notlar tutulmuştur. Araştırmaya katılan katılımcıların görüşleri gizlilik ilkesi dikkate alınarak isimleri verilmeden kodlanmıştır. Görüşme yapılan kişiler K1, K2, K3 şeklinde sıralanmış ve katılımcılara K1 ile K13 arasında kodlar araştırma kısmında yerel halk için on iki yedi ve bağcılar için beş sorudan oluşan yarı yapılandırılmış görüşme formu yardımıyla on üç katılımcı ile yüz yüze görüşme 
Kırsal Turizmin Gelişsimine Yönelik Yerel Halkın Yaklaşımı: Avanos Göynük Köyü Üzerine Bir Araştırma Eda Özgül KATLAV, Derman KÜÇÜKALTAN

yapılmıştır. Çalışmaya derinlik ve zenginlik kazandırması açısından gerekli görülen durumlarda görüşme formu dışında ilave sorular da sorulmuştur. Görüşmelerin süresi 34 dakika ile 70 dakika arasında değişiklik göstermektedir. Görüşmelerin sürelerine bakıldığında ortalama 46 dakika olduğu görülmektedir. Görüşmelerde alınan ses kayıtları yazılı hale getirilmiş, ardından kayıtlar tekrar dinlenilerek yazılı metin ile karşılaştırılmış ve metinlerin doğrulaması yapılmıştır. Alınan ses kayıtları ve notlar yazılı hale getirilerek elde edilen verilere içerik analizi uygulanmıştır.

\section{Geçerlilik (İnandırıcılık)}

Nitel araştırmalarda elde edilen verilerin geçerlilik ve güvenirliğini ölçmek için çeşitli yöntemlere (inandırıcılık, aktarılabilirlik, tutarlılık ve teyit edilebilirlik) başvurulmaktadır. $\mathrm{Bu}$ araştırmalarda geçerlilik ve güvenirliği sağlayabilmek için araştırmacının araştırdığı olguyu, olduğu biçimiyle olabildiğince yansız gözlemesi ve elde ettiği veriyi, ulaştığı sonuçları teyit etmesine yardımcı olacak çeşitleme, katılımcı teyidi, meslektaş teyidi gibi ek yöntemler kullanması gerekmektedir. Nitel geçerliliği sağlamak için kullanılan yöntemlerden biri olan inandırıcılık; süreli etkileşim, derinlik odaklı veri toplama, çeşitleme, uzman incelemesi, katılımcı teyidi yöntemleri ile test edilmektedir (Yıldırım ve Şimşek, 2016; Güler, Hacıoğlu ve Taşğın, 2015). İnandırıcılığın sağlanabilmesi için araştırmacıların elde ettikleri verilerin ve sonuçların katılımcıların söylediği ifadeleri doğru bir şekilde yansıtması, birden fazla ve çeşitli kaynaklardan elde edilen bilgilerin çalışmadaki tema ve kategoriler ile ortak paydada buluşması (Güler, Hacıŏ̆lu ve Taşğın, 2015), araştırmacılar arasında kod şemaları oluşturulması ve kategorilerin belirlenmesi için tartışmalar yapılması (Yılmaz ve Özdemir, 2017) gibi yöntemler bulunmaktadır. Bu çalışmada bu hususlara dikkat edilmiştir. Bu kapsamda öncelikle içerik analizi aşamasında bir kod şeması oluşturulmuş ve araştırmacılar tarafından kod şemaları kullanılarak ayrı ayrı kodlamalar yapılmış ve bu kodlamalar ile ilgili tartışmalar yapılmıştır. Araştırmanın yöntemine ilişkin ayrıntılı bilgiler verilmiş ve bulgular kısmında doğrudan alıntılar yer almıştır. Ayrıca araştırmaya katılan katılımcılara görüşme sonunda konu hakkındaki görüşleri özetlenerek onayları alınmıştır. Araştırmaya katılan paydaşlar elde edilen bulguların bölge için doğruluğunu ifade ederek kendi gerçekliklerini yansıttığını belirtmiştir.

\section{Araştırma Bulguları}

$\mathrm{Bu}$ bölümde öncelikle doküman incelemelerine ilişkin bulgulara yer verilmiş, sonrasında da görüşmelere ilişkin bulgular ayrıntılı bir şekilde değerlendirilmiştir. Bağcılık ve tarım turizmi ilişkisi ile ilgili dökümanlar incelendiğinde tarım turizminin kapsadığı bağcılığın çevresel ve ekolojik bakımdan sürdürülebilir bir özelliğe sahip olduğu görülmektedir. Ayrıca bağcılıkla birlikte tarım turizmi ve dolayısıyla kırsal turizm, ekonomik açıdan bölgeye katkı sağlayabilmekte, bağcılık yapılan alanlarda gelişimi desteklemekte ve sosyal anlamda kabul edilebilir bir yapıya sahip olmaktadır. Bağcılık ve tarım turizmi ekonomik açıdan kalkınmayı desteklediğinden ülkemiz açısından büyük bir öneme sahiptir. Doküman incelemesi bulgularına göre Türkiye'de bağcılık ve tarım turizm ilişkisinin gelişmesi ve etkin bir şekilde sürdürülebilmesi için bağcılık ve turizm paydaşları arasında güçlü bir fikir birliği olduğu söylenebilir. Nevşehir İli Göynük Köyü’nde bağcılık konusunda çok özel bir tarihi, ekolojik ortamı ve asma fidanların/çubuklarının genetik özelliklerinin olduğu görülmektedir. Ayrıca bölgeye has olan emir, dimrit gibi üzüm çeşitleri ve bu üzümlerde 
üretilen yöresel ürünler bulunmaktadır. Göynük Köyü’nde yaşayanların bağcılığın ve kırsal turizm kapsamında değerlendirilmesinin önemini kavramış durumda olduğu görülmektedir. Ayrıca bağcılıktan elde edilen ürünlerin yöresel ürünlere dönüştürülmesi konusuna önem verdikleri tespit edilmiştir. Yapılan araştırma sonucunda köyde yapılan bağcılığın Kooperatif ve bağcıların çabaları ile bir yere geldiği görülmektedir. Ancak bu çabaların tam olarak yeterli olmadığı köylülerin bu konuda uzman kişilerden ve devletten destek beklediği ortaya çıkmıştır. Ayrıca köyde tarım turizmine yönelik faaliyetlerin gerçekleştirilmesine köy halkının ve üreticilerin (bağcılar) 1lımlı baktığını söylemek mümkündür. Bu konuda şehirde bulunan kamu temsilciler, üniversite ve diğer köylerde bulunan bağcılarla işbirliği yapmak istediklerini ifade etmişlerdir.

Görüşmelerden elde edilen veriler betimsel ve içerik analizi ile çözümlenmiş ve sonuçları şöyle özetlenmiştir: Nevşehir genelinde eskiden olduğu gibi insanların bağcılıkla uğraşmadığı ve bağ alanlarının bakımsız olduğu ya da satıldığı görülmektedir. Göynük Köyü'nde bağcılık Nevşehir geneline göre oldukça iyi durumdadır. Ancak bağcılığın gelişimi için devlet destekleri artmazsa ilerleyen yıllarda bu durumun aksine bir seyir alacağı düşünülmektedir. Ayrıca Göynük'te yaşayan yerel halkın ve çifçilerin (bağcılar) turizme karşı oldukça yakın bir tavır sergiledikleri görülmektedir. Köyün ve bağcılığın turizmle beraber daha fazla gelişeceği inancı bulunmaktadır. Bu köyde yaşayan ve üreten insanlar köye bu amaçla gelen turistlere yardımcı olduklarını ve olacaklarını ifade etmişlerdir. Ayrıca turistlerin ilgisini çekebilecek yöresel ürünler ortaya çıkarıp, bunları satmak için satış ofisleri açmak, eski evleri restore edip konaklama tesisleri açmak istediklerini belirtmişlerdir. $\mathrm{Bu}$ durum, Göynük'deki sosyal yapının yalnızca tarım turizmine değil, kırsal turizme de yatkın olduğunu göstermektedir.

\section{Katılımcilara Ait Demografik Bulgular}

Araştırmaya katılan katılımcıların demografik özelliklerini Tablo 1'de özetlenmiştir.

Tablo 1. Araştırmaya Katılanların Demografik Özelikleri

\begin{tabular}{|l|l|l|l|l|}
\hline Katılımcı & Cinsiyet & Yaş & $\begin{array}{l}\text { Eğitim } \\
\text { Durumu }\end{array}$ & Meslek \\
\hline K1 & Erkek & 52 & Lise & Emekli ve bağc1 (çiftçi) \\
\hline K2 & Erkek & 32 & Önlisans & Bir otelde resepsiyonist, kendi bağ1 var \\
\hline K3 & Erkek & 46 & Lise & Memur, acente sahibi, bağc1 (çiftçi) \\
\hline K4 & Erkek & 59 & İlkokul & Emekli ve bağc1 (çiftçi) \\
\hline K5 & Erkek & 38 & Lise & $\begin{array}{l}\text { İç dekorasyon, inşaat işleri, kendi bağ1 } \\
\text { var }\end{array}$ \\
\hline K6 & Erkek & 24 & Lisans & Bağc1 (çiftçi) \\
\hline K7 & Erkek & 38 & Lise & Bağc1 (çiftçi) \\
\hline K8 & Erkek & 56 & İlkokul & Bağc1 (çiftçi) \\
\hline K9 & Kadın & 44 & İlkokul & Evhanım1, Bağc1 (çiftçi) \\
\hline K10 & Erkek & 88 & İlkokul & Emekli, kendi bağ1 var \\
\hline K11 & Erkek & 63 & Lise & Bağc1 (çiftçi) \\
\hline K12 & Kadın & 42 & Lise & Evhanımı, Bağc1 (çiftçi) \\
\hline K13 & Kadın & 54 & İlkokul & Bağc1 (çiftçi) \\
\hline
\end{tabular}


Kırsal Turizmin Gelişsimine Yönelik Yerel Halkın Yaklaşımı: Avanos Göynük Köyü Üzerine Bir Araştırma Eda Özgül KATLAV, Derman KÜÇÜKALTAN

Tablo 1. İncelendiğinde araştırmaya katılanların çoğunun erkek, 30 yaşından büyük olduğu, genelinin lise mezunu olduğu ve hepsinin bağı olduğu görülmektedir. Tablo 1.'de araştırmaya katılanların bir kısmının bağcılığı hobi olarak yaptığı, bir kısmının ise büyük çapta üretim yatığ 1 görülmektedir. Bu nedenle araştırmaya katılan katılımcılara yöneltilen sorularda farklılıklar bulunmaktadır. Dolayısıyla sorular farklılık gösterdiği için görüşmeler iki ayrı başlık altında ele alınmıştır. Yerel halk (bağcılığı hobi olarak yapan) ve bağcılığı profesyonel şekilde yapan (çiftçiler/bağcılar) kişilere ilişkin görüşme sonuçları sırasıyla verilmişstir.

\section{Yerel Halka İlişkin Araştırma Bulguları}

Görüşmelere başlamadan önce araştırmaya katılan kişilerle ilgili demografik sorular sorulmuştur. Bu soruların bir kısmı Tablo 1.'de özetlenmiştir. Ayrıca Göynük ve bağcılık hakkında detaylı bilgi verebilmeleri amacıyla katılımcıların Göynük'lü olması ve uzun yıllar o yörede yaşamış olması durumu temel alınmıştır. Bu nedenle araştırmaya katılan kişilerin hepsi Göynük köyü doğumlu ve en az beş yıldır Göynük’te ikamet etmektedir. Katılımcıların bazıları bir aile geleneği olarak bağcılıkla uğraşırken, bazıları ciddi anlamda üretim yapmaktadır. Bir aile geleneği olarak bağcılıkla uğraşan katılımcılar kendi ailelerine yetecek kadar ürün almakta, bu ürünleri işlemekte ve kendileri tüketmektedir. Ancak profesyonel anlamda bağcılıkla uğraşan katılımcılar üzümlerin büyük bir kısmını yaş olarak çevre illerde bulunan hallere satmakta, talebe göre bir kısmını pekmez ya da üzümden üretilen yöresel ürünlere dönüştürmektedir.

Katılımcılara ilk olarak "Geçiminizi nasıl sağlıyorsunuz ?" sorusu sorulmuştur. Genel olarak katılımcıların verdiği cevap emekliyim, turizm çalışanıyım, turizm acentesi sahibiyim, inşaat işleri ile uğraşıyorum, memurum şeklinde olmuştur. Ancak bunun yanında küçük çapta da olsa bağcılıkla uğraştıklarını belirtmişlerdir. K3 bu soruya "ben memurum, ayn zamanda turizme de yakınım. Acente işletiyoruz. Bunun yanında da bă̆ımız var büyük çapta olmasa da bă̆cılıkla uğraşmaktayım” demiş; K2 ise "Turizmciyim. İki yıllık turizm okudum şimdi de bir otelde çalışıyorum.” yanıtını vermiştir.

“Turistlerin Nevşehir'e neden geldiklerini düşünüyorsunuz?" ve "Sizin köyünüze neredeyse $5 \mathrm{~km}$ uzaklıkta Özkonak Beldesi'nde bulunan yeraltı şehrine gelen turistlerin Göynük Köyü'nü ziyaret etmelerini ister misiniz?" soruları sorulmuştur. Katılımcıların \% 70'inin cevapları; "Nevşehir'de peri bacaları var, doğal unsurlar çok farklı turistlerin ilgisini çekiyor şeklinde olmuştur. Ayrıca Nevşehir'de Hristiyanlık tarihine ait önemli kiliseler, yeraltı şehirlerinin olduğunu ifade etmişlerdir. Bir diğer yanıt ise turistlerin balona binmek için bölgeye geldiği şeklindedir. K12 bu soruya "Nevşehir'in dünyada eşi benzeri yok, peri bacaları turistlerin ilgisini çekiyor. Bir de yeraltı şehirleri ve kiliseler var" demiş ve K9 ise "Balona binmek için geliyorlar, balona binince bölge çok güzel görünüyor.” diye ifade etmiştir. Özkonak Beldesine gelen kişilerin köyünüzü ziyaret etmesini ister misiniz sorusuna ise genel olarak katılımcıların hemen hepsi olumlu yanıt vermiştir. Turistlerin gelip bağlarını görmelerini istediklerini belirtmişlerdir. K8 bu soruya "İsterim. Köyümüzde turizm potansiyeli var ama değerlendirilmiyor" diye yanıt vermiştir. $\mathrm{K} 5$ ise "Köyümüze turistlerin gelmesini istiyoruz. Özkonak buraya $5 \mathrm{~km}$ uzaklıkta ayrıca köyümüz Avanos'a bağlı ve çok yakın ancak oraya gelen turistler de köyümüzü tanımıyor." demiştir. 
Kırsal Turizmin Gelişimine Yönelik Yerel Halkın Yaklaşımı: Avanos Göynük Köyü Üzerine Bir Araştırma Eda Özgül KATLAV, Derman KÜÇÜKALTAN

Katılımcılara Göynük Köyü turistler tarafından ziyaret edilse ekonomik, sosyal ve çevresel anlamda nasıl bir etkisi olur? sorusu yöneltilmiş ve katılımcıların yaklaşık \%80'ini şöyle yanıtlar vermiştir. Ekonomik anlamda katkısının çok olacağı çünkü bağcılığın yılın sadece belirli bir zamanında gelir getirdiği ve bunun tüm yıl içerisinde kullanıldığı diğer aylarda bundan başka geliri olmayan insanlar için sorun olabildiği ifade edilmiş̧tir. Ayrıca bu sebepten dolayı köyde istihdam olanaklarının az olduğu ve insanların çalışmak için çevredeki illere göçtüğü belirtilmiştir. K10 bu soruya "Bağclllk ve tarım köyümüzün temel geçim kaynăğ. Ancak yılın belirli bir zamanında gelir getiriyor. Ayrıca bağcılık yapabilmek için giderlerimiz (tarımsal ilaç alımları, işçilik ücretleri, vb) de oluyor. Bu nedenle turizm köye ekonomik anlamda katkı sağlayacaktır." ve K4 ise "Köyde bağcılık var, balık yetiştiriciliği var. Ancak turizme bu kadar yakın bir yerde turizmle ilgili bir şey yok. Köylülerin tarım faaliyetlerine devam edebilmesinde turizmin faydalı olacağını düşünüyorum." şeklinde yanıt vermişlerdir.

Turistlerin köyü ziyaret etmelerinin sosyal anlamda etkilerinin neler olabileceğine ilişkin araştırmaya katılanlar yaşam standartlarının artacağını düşünmektedir. Turizmle birlikte köyde yeme-içme alanlarının açılabileceğini, yöresel ürünlerin ve kültürlerinin diğer kişilerle paylaşılabileceğini söylemişlerdir. K6 bu soruya "Turizmin sosyal anlamda birçok olumu katkısı var. Köyümüz için de bu katkının olacağını düşünüyorum. Örneğin turizmle birlikte dikkat çekecek kültürel unsurlara yönelim artacaktır." ve " K13 "Turistler köyümüzün kültürünü ögrenir, yemeklerini yer, köyde iş imkanı artar gençler için" yanıtlarını vermişlerdir. Turistlerin köyü ziyaret etmelerinin çevresel anlamda nasıl bir etki yaratacağı sorusuna genel olarak köyde bulunan eski evlerin restore edilerek köyün çehresinin değişeceğini, bağcıların bağ alanlarını daha özenli bir şekilde düzenleyeceğini, yolların, çevre düzenlemesinin ona göre yapılacağı yanıtlarını vermişlerdir. Ancak bu noktada genel olarak turizm gelişiminin planlı bir şekilde yapılmasına yönelik talepleri bulunmaktadır. Çevre beldelerde ya da köylerde turizmin plansız gelişimi sonucunda yörede olan tahribatın farkında oldukları için aynı durumun köy için olmaması katılımcıların ortak kanaatidir. K6 bu soruya "Bölge güzelleşir. Köyde çevre düzenlemesi yapılabilir. Benim bağım oldukça bakıml ve dikkat çekici ancak çevresinde bulunan evlerin bahçelerinin görüntüsü çok kötü ya da diğer bağcllar bizim kadar önem vermeyebiliyor. Bu anlamda katkısı olacaktır. Olumsuz anlamda ise ĕger planlı bir gelişim olmazsa turizmin yıkıcı etkileri de olabilir. Buna dikkat etmek gerekir." diye belirtmiştir.

“Nevşehir'de ve Göynük Köyü'nde konaklama tesisleri sizce yeterli midir?" ve "Sizin köyünüzü yerli turistler mi yoksa yabancı turistler mi daha çok tercih ediyor?" sorularına verilen yanıtlar şöyle özetlenebilir. Katılımcılar Nevşehir'de ve özellikle Nevşehir Merkez, Göreme, Ürgüp, Uçhisar, Avanos merkezde bulunan konaklama tesislerinin konaklama imkanlarının yeterli olduğunu ancak zamanla buraların yeterli olamayacağını belirtmişlerdir. Ancak Göynük Köyü’nde konaklama tesisi bulunmamaktadır. En yakın konaklama tesisleri bağlı bulunduğu ilçe olan Avanos'ta bulunmaktadır. Ancak talep olması halinde köyde bulunan eski evlerin otel olarak kullanılabileceğini belirtmişlerdir. Ayrıca katılımcılar köylerini şimdiye kadar ziyaret eden turist sayısının oldukça az olduğunu, köy ve kooperatif tarafından düzenlenene Bağbozumu Festivali sırasında yerli turistlerin daha yoğunlukla köylerine geldiğini ya da çevre iller olan Kayseri, Niğde, Aksaray, Kırşehir gibi illerden üzüm almaya gelen yerli 
Kırsal Turizmin Gelişimine Yönelik Yerel Halkın Yaklaşımı: Avanos Göynük Köyü Üzerine Bir Araştırma Eda Özgül KATLAV, Derman KÜÇÜKALTAN

turistlerin olduğunu ifade etmişlerdir. K7 "Otel yok ama biz Bağbozumu Festivali için buraya gelen konuklara köyde kalacak yer ayarladık. Onun dışında Avanos buraya çok yakın ve konaklama, yiyecek-içecekle ilgili yerler mevcut” demiştir.

"Yöreye gelen turistlerin konaklaması ya da yeme-içmeleri için evlerinizi açar mısınız? Sorusuna araştırmaya katılan katılımcılar oldukça olumlu yaklaştıklarını belirtmişlerdir. Zaman zaman yapılan etkinliklerde yöre halkı evini açtığını söylemiştir. Bazı kişiler ise doğrudan kaldığı ev olmasa da ikinci bir evi varsa orada ağırlayabileceğini ifade etmiştir. Ancak gelen turist sayısının artması durumunda köyde otel açabilecek kişilerin olduğu da eklenmiştir. K1 ise bu soruya "Gelen turistler dilerseler evlerimizi açarız. Ancak böyle bir talep olması halinde kendi köyümüzde otel de açabiliriz." yanıtını vermiştir. $\mathrm{Bu}$ yanıt yörenin kırsal turizm için uygun bir yapıya sahip olduğunu göstermektedir.

\section{Çiftçilere Yönelik Araştırma Sonuçları}

$\mathrm{Bu}$ kısımda yörede bağcılığı profesyonel anlamda yapan kişilere sorular yöneltilmiştir. Yerel halka sorulan sorulardan bazıları farklılık göstermektedir. Aşağıda sorular ve verilen yanıtlar özetlenmiștir.

“Geçiminizi nasıl sağlıyorsunuz? " ve "Kaç yıldır bağcılıkla uğraşıyorsunuz ?" soruları bağcılara yönetilmiş ve yaklaşık \% 77'si geçimlerini sadece tarımla sağladıklarını ve bunun büyük bir kısmını bağcılıktan kazandıklarını ifade etmişlerdir. Bu kişiler bağcılıkla küçük yaşlardan itibaren ilgili olduklarını çünkü ailelerinin bu işi yaptıklarını belirtmiş̧lerdir. K6 bu soruyu; "Geçimimizi bağcılıktan sağllyoruz. Eşim ölmeden önce bağlarımız vardı. Onunla beraber băg görürdük. O ölünce bağlarımızla ben ve çocuklarım ilgileniyoruz. Bă̆cılı̆̆ dedelerimiz, anne babalarımızdan öğrendik hala da devam ettiriyoruz." şeklinde cevaplamıştır.

"Sizce Nevşehir'de bağcılık gereken ilgiyi görüyor mu?" sorusuna araştırmaya katılanların yaklaşık \%82'si Nevşehir genelinde bağcılığın bırakılmaya çalışan bir meslek haline geldiğini söylemişlerdir. Çünkü Nevşehir'de turizmin önem kazanmasıyla sonucunda birçok kişinin turizmden gelir elde ettiğini ve turizmin yoğun olarak yapıldığ alanlarda bağ alanlarının artık işlenmediği ifade etmişlerdir. Ancak bazı köyler de ki bu köylerin içinde üretim miktarı olarak başı çekenlerin biri olan Göynük Köyü'nde tarım ve bağcılık aktif olarak yapıldığı söylenmektedir. Ancak şu anda köyde bağcılığı yapan kişilerin genellikle 40 yaş ve üstü insanlar olduğu gençlerden parmakla sayılacak kadarının bağcılığ1 meslek edindiği de eklenmektedir. K11 bu konuda şunu söylemektedir " Köyde 40 yaşının üstü kişiler bağcılık yapmasa bağcllık biter." Ayrıca araştırmaya katılan bağcıların ortak görüşü şöyledir; bağcılıktan elde edilen kazancın yıl içine yayılmaması, üzüm fiyatlarına devletin taban fiyat belirlememesi gibi unsurlar mevcutta bağcılık yapan kişilerin de bu işi büyük miktarlarda yapmamasına neden olmaktadır.

"Başka ülkelerde bağcılıkla uğraşan çiftçiler sizin üretim yöntemlerinizi görmek için gelse onlarla üretim yöntemlerinizi paylaşır mısınız?" sorusuna araştırmaya katılan bütün çiftçiler evet yanıtı vermişler ve köyde bulunan çiftçilerin modern üretim yöntemlerini kullandıklarını ancak bunları kendi yöntemleri ile öğrendiklerini eklemişlerdir. Bu amaçla köyü ziyaret eden çiftçilerin kendilerine ve kendilerinin de onlara 
Kırsal Turizmin Gelişsimine Yönelik Yerel Halkın Yaklaşımı: Avanos Göynük Köyü Üzerine Bir Araştırma Eda Özgül KATLAV, Derman KÜÇÜKALTAN

katk1 sağlayacağ1 düşüncesindedirler. K1 "Biz geçen senelerde üzüm asmalarının arasını 2 metre yapmıştık ama iyi verim alamadık, sonra kooperatifteki üreticiler bize 4 metre olması gerektiğini söyledi biz de yaptık ve daha fazla ürün aldık. Ancak Manisa bağlarında bu asmaların arası 2 metre bunu bilmemek bizim bir yılımıza sebep oldu” demiştir. Ayrıca çiftçiler bağcilıkta kendilerinden iyi olan ülkelerin üretim yöntemlerini öğrenmek istemektedirler.

“Sizce Göynük’te tarım ve turizmi bir arada ele alabileceğiniz tarım turizm faaliyetleri gerçekleştirilebilir mi?" sorusuna katılımcılar olumlu yanıt vermişler ve dünyada böyle örneklerin olduğunu köyün de bu turizm için uygun olduğunu belirtmişlerdir. K8 bu soruya “ Italya yaş üzüm üreten bir ülke ve bu tür turizm orada yapılıyor. Biz de bunu yapabiliriz. Sadece nasıl yapllacă̆ konusunda sizlerden, kamu kurumları, turizmcilerden destek bekliyoruz." demiştir.

"Kırsal turizm faaliyetleri bu köyde gerçekleşse nasıl katkı sağlarsınız?" sorusuna ise bağcılar olarak biz bağ alanlarını açabileceklerini, kooperatifimizin tüm imkanlarını kullanabileceklerini ve bu konuda proje işbirliklerine açık olduklarını ifade etmişlerdir. Köyde bağların turistlere gösterilebileceği bir alan yaratabileceklerini, üzümden elde edilen ürünlerle yöresel ürün satan işletmeler açabileceklerini, konaklama ile imkan sağlayabilecekleri belirtmişlerdir. K6 “ Benim bu konuda yapmak istediklerim var köy pek bu anlamda ziyaret edilmediği için Avanos'a köyün ürünlerini satabileceğim bir işletme açmak istiyorum." diye söylemiştir.

\section{SONUÇ VE DEĞERLENDİRME}

Günümüzde dünyada ve Türkiye'de turistler deniz, kum ve güneş anlayışının yanı sıra alternatif turizm türlerini tercih etmeye başlamıştır. Bu alternatif turizm türlerinden biri de turistlerin kırsal alanlara turizm faaliyetinde bulunarak buralarda yayla, orman, mesire yerleri, kırsal pazar vb. yerlerde vakit geçirmeyi sağlayarak turizmde geri kalmış yerleri geliştirmek ve bölgeye ek gelir kaynağı yaratarak istihdama olanak sağlayan kırsal turizmdir (Dursun, vd.,2017, s. 1). Kırsal turizm kırsal alanlarda kırsal kalkınmay1 sağlamakta ve çoğu zaman tarım, hayvancılık gibi kırsal alanlarda yapılan işlerde bu işleri yapanlara ek gelir getiren ve onları destekleyen bir yaklaşım sergilemektedir. Kırsal turizm gelişmiş ve gelişmekte olan ülkelerin kalınmada önem verdiği önemli araçlardan biri haline gelmiştir. Ülkeler kırsal turizme ülke politikaları içinde yer vermekte, teşvik ve hibelerle desteklemekte, yasalarla korumaktadır. Türkiye'de bu anlamda kırsal kalkınmayı sağlayabilmek adına turizm politikalarında kırsal turizme yer vermekte ve bu anlamda bu girişimleri desteklemektedir. Türkiye Turizm Stratejisi 2023 ve III. Turizm Şûrası'nda kırsal turizmin önemine gereken vurgu yapılmıştır ve bu anlamda tedbirler ve kararlar almıştır.

Ülkeler için bu kadar önemli olan kırsal turizm faaliyetlerinin bir yörede planlanması ve uygulanabilmesi için orada yaşayan yerel halk ve çiftçilerin bu duruma karşı tutumları önemli olmaktadır. Bu nedenle kırsal alanlarda kırsal turizm faaliyetleri planlanmadan önce yerel halkın tutumları öğrenilmeli ve bu sürece dahil edilmelidir. Bu çalışmada temel 
Kırsal Turizmin Gelişsimine Yönelik Yerel Halkın Yaklaşımı: Avanos Göynük Köyü Üzerine Bir Araştırma Eda Özgül KATLAV, Derman KÜÇÜKALTAN

ekonomik kaynağı tarım ve turizm olan Nevşehir'de kırsal turizmin geliştirilebilirliği araştırılmaktadır. Bu kapsamda bu çalışmada Nevşehir'e bağlı ve temel geçim kaynağı bağcılık olan, ülke genelinin yaş üzüm ihtiyacını önemli ölçüde karşılayan Avanos ilçesine bağlı Göynük Köyü'nde tarım turizminin uygulanabilirliği üzerine bir çalışma yapılmıştır. $\mathrm{Bu}$ çalışma bir ön çalışma niteliğinde olup daha sonra konu ile ilgili diğer paydaşlarla görüşülecek ve bölgede tarım turizminin geliştirilmesine yönelik çabalar gerçekleştirilecektir.

Araştırma kapsamında derinlemesine bilgi alabilmek adına nitel araştırma yöntemlerine başvurulmuş ve mülakat yoluyla veri elde edilmiştir. Göynük Köyü'nde yaşayan 13 kişi araştırmaya dahil edilmiş ve tarım turizminin köyde geliştirilmesine yönelik düşünceleri öğrenilmiştir. Araştırma sonucunda köyde yaşayan ve söz sahibi olan kişilerin tarım turizmine yönelik olumlu bir kanaatlerinin olduğu ve bu konuda istekli oldukları görülmektedir. Göynük halkı bağcılıktan gelir elde etmekte ve bağcılığı devam ettirmek istemektedir. Ayrıca araştırmaya katılan kişilerin turizm bilinci olduğu görülmüştür. Göynük Köyü'nde yalnızca tarım turizminin değil, daha geniş boyutlu kırsal turizmin de planlanması ve yapılabilmesi için yerel halk ve çiftçiler Valilik, Belediyeler, İl Kültür Turizm Müdürlüğü, Kapadokya Turizm Geliştirme Altyapı Birliği, İl Tarım Müdürlüğü, Üniversite, sivil toplum kuruluşları, çiftçiler ve turizmcilerle işbirliği yapmak istemektedirler.

$\mathrm{Bu}$ çalışma sonucunda Göynük Köyü'nde kırsal turizmin geliştirilebilmesi için bazı öneriler geliştirilmiştir. Buna göre, Öncelikle köyde bağc1lıkla uğraşan çiftçilere bağcılık ve turizm bilinci ile ilgili eğitim verilmesi, bağcılık üretim yöntemleri ile ilgili uzman desteği verilmesi gerekmektedir. Kamu yerel halkı ve çiftçileri tarım turizmine teşvik edici uygulamalar ya da hibe imkânı sunabilir. Ancak bu imkanları sunarken onlara bunu nasıl yapacaklarına dair eğimler vermesi gerekmektedir. Yerel halka, pansiyonculuk anlamında eğitimler verilebilir. Yerel halk ve turizm acenteleri ya da sivil toplum kuruluşları ortak etkinlikler, gezi turları, vb. organizasyonları ortak programlar düzenleyebilirler. Diğer ülkelerin bağcıları ile köyde üretim yapan bağcılar bir araya getirilerek üretim yöntemleri hakkında görüşmeler yapabilir. Gelen turistlerin hasat zamanı bağlarda ürün toplamasına ve satın almasına yönelik uygulamalar gerçekleştirilebilir. Ayrıca köyde gerçekleştirilen Uluslararası Bağbozumu Festivallerini gerçek manada uluslararası organizasyona dönüştürebilmek için gerekli adımlar atılabilir. Kapadokya'nın ulusal ve uluslararası bağlamda tanınmışlığını, kırsal turizm boyutuyla da yaygınlaştırmak hem üreticilerin tarımsal etkinliğini daha iyi değerlendirmek, hem de yerel kültürün tanıtılmasına daha iyi katk1 sağlayabilecektir. Turizmde geleceğin, küreselleşme rüzgarından yerel kültürünü korumayı başarabilmiş yörelerin olacağı unutulmamalıdır. 


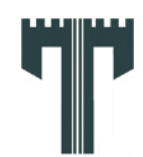

Gastroia: Journal of Gastronomy and Travel Research, Vol. 3, Issue 4 (Özel Sayı), 739-752, 2019

Kırsal Turizmin Gelişimine Yönelik Yerel Halkın Yaklaşımı: Avanos Göynük Köyü Üzerine Bir Araştırma Eda Özgül KATLAV, Derman KÜÇÜKALTAN

\section{KAYNAKÇA}

Ahika, 2017, Nevşehir 2017 Yatırım Destek ve Tanıtım Stratejisi: Link: https://ahika.gov.tr/assets/ilgilidosyalar/AHIKA_YDTS_NEVSEHIR_FINAL_27EYLUL.pdf (Erişim Tarihi: 15.02.2019

Cengiz, T., \& Çelem, H. (2005). Hızlı kırsal değerlendirme yöntemi: alpağut köyü örneği (seben, bolu).

Çeken, H., Karadağ, L., \& Dalgın, T. (2007). Kırsal kalkınmada yeni bir yaklaşım kırsal turizm ve Türkiye'ye yönelik teorik bir çalışma, Artvin Çoruh Üniversitesi Orman Fakültesi Dergisi, 8 (1), 1-14 (2007)

European Commission. (2000),Towards Quality Rural Tourism: Integrated Quality Management (IQM) for Coastal Destinations, Office for Official Publications of European Communities, Luxembourg.

Güler, A., Halıcıŏlu, M. B., \& Taşğın, S. (2013). Sosyal bilimlerde nitel araştırma yöntemleri. Ankara: Seçkin Yayıncılık.

Kapadokya Ulusal Bağcılık Çalıştayı, (2016). Sonuç Raporu. Gıda, Tarım ve Hayvancılık Bakanlığ1. Link: https://nevsehir.tarim.gov.tr/Haber/473/Kapadokya-Ulusal-BagcilikCalistayi-Sonuc-Raporu-Yayinlandi (Erişim Tarihi: 01.03.2018)

Kiracı, M. A., \& Şenol, M. A. (2017). Türkiye Bağcılığında Ekonomik Durum Analizi. Nevşehir Bilim ve Teknoloji Dergisi, 6, 122-131.

Kizos, T. ve Lozifides, T. (2007). The contradictions of agrotourism development in Greece: Evidence from three case studies. South European Society \& Politics, 12(1), 59-77.

Küçükaltan, D., \& Ultanır, G. (2012). Trakya'da kırsal turizmin uygulanabilirliği: Şarköy örneği, KMÜ Sosyal ve Ekonomik Araştırmalar Dergisi, 14 (22), 125-130,

Maruti, K.V. (2009) Agrotourism: scope and opportunities for the farmers in Maharashtra. Article Report. Dept. of Economics, Y.C. College. Pachwad Tal-Wai, Dist-Satara, State Maharashtra. 12. p.

Miles, M. B., \& Huberman, A. M. (1994). Qualitative data analysis: An expanded sourcebook. sage.

Seidman, I. (2006). Interviewing as Qualitative Research: A Guide for Researchers in Education and The Social Sciences Teachers College Press. New York, NY.

Semerci, A., Kızıltuğ, T., Çelik, A. D., \& Kiracı, M. A. (2015). Türkiye bağcılığının genel durumu. Mustafa Kemal Üniversitesi Ziraat Fakültesi Dergisi, 20(2).

Topçu, E. D. (2007). Agri-tourism: As a new element of country planning. Basılmamış Yüksek Lisans Tezi. Ortadoğu Teknik Üniversitesi Fen Bilimleri Enstitüsü, Ankara.

Tuna, M., Katlav Ö. E. \& Eren Y. F. (2018) Kapadokya'da Bağcılığın Gastronomi Turizmi Açısından Değerlendirilmesi, 19. Ulusal Turizm Kongresi, 17-20 Ekim 2018, Afyon. 
Gastroia: Journal of Gastronomy and Travel Research, Vol. 3, Issue 4 (Özel Sayl), 739-752, 2019

Kırsal Turizmin Gelişsimine Yönelik Yerel Halkın Yaklaşımı: Avanos Göynük Köyü Üzerine Bir Araştırma Eda Özgül KATLAV, Derman KÜÇÜKALTAN

Türkben, C., Fulya, G. Ü. L., \& Yılmaz, U. Z. A. R. (2012). Türkiye'de Bağcılığın Tarım Turizmi (Agro-Turizm) İçinde Yeri ve Önemi. Karamanoğlu Mehmetbey Üniversitesi Sosyal Ve Ekonomik Araştırmalar Dergisi, 2012(2), 47-50.

Uysal, T., \& Yaşasın, A. S. (2017). Asma Genetik Kaynaklarımız ve Nevşehir İli Üzüm Çeşitleri. Nevşehir Bilim ve Teknoloji Dergisi, 6, 132-136.

Yalçın, M. (2006). A’dan Z’ye Şarap. Gusto Kitapları, Baküs Yayıncılık

Yıldırım, A., \& Şimşek, H. (2016). Nitel araştırma yöntemleri.(10. Bask1). Ankara: Seçkin Yayıncillk.

Yılmaz, G., \& Özdemir, B. (2017). Turizm Destinasyonlarında Restoran Biçimleşmeleri: Kapadokya Bölgesi Üzerine Nitel Bir Araştırma. Anatolia: Turizm Araştırmaları Dergisi, 28(1), 81-95.

Yozukmaz, N., Ekiztepe, B. A., \& Çeken, H. (2014). Kırsal Turizmin Önemi: Dünyada ve Türkiye'de Kırsal Turizm Uygulamaları. Uluslararası Sosyal ve Ekonomik Bilimler Dergisi, (2), 37-44. 